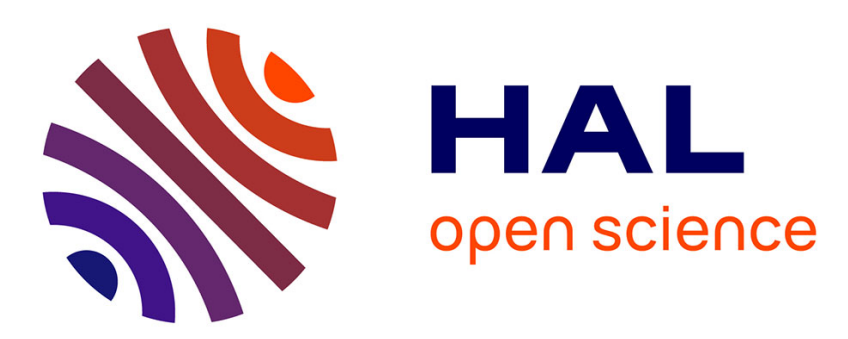

\title{
First fossil occurrence of the jewel damselflies (Odonata: Chlorocyphidae): a new species from the Late Miocene of Styria, Austria
}

\author{
André Nel, Martin Gross, Michael S. Engel
}

\section{- To cite this version:}

André Nel, Martin Gross, Michael S. Engel. First fossil occurrence of the jewel damselflies (Odonata: Chlorocyphidae): a new species from the Late Miocene of Styria, Austria. Annales de la Société Entomologique de France, 2017, 53 (4), pp.280-285. 10.1080/00379271.2017.1342559 . hal-01613276

\section{HAL Id: hal-01613276 \\ https://hal.sorbonne-universite.fr/hal-01613276}

Submitted on 9 Oct 2017

HAL is a multi-disciplinary open access archive for the deposit and dissemination of scientific research documents, whether they are published or not. The documents may come from teaching and research institutions in France or abroad, or from public or private research centers.
L'archive ouverte pluridisciplinaire HAL, est destinée au dépôt et à la diffusion de documents scientifiques de niveau recherche, publiés ou non, émanant des établissements d'enseignement et de recherche français ou étrangers, des laboratoires publics ou privés. 
Annales de la Société Entomologique de France

First fossil occurrence of the jewel damselflies (Odonata: Chlorocyphidae): A new species from the Late Miocene of Styria, Austria

ANDRE NeL ${ }^{(1)}$, MARTIN Gross $^{(2)}, \&$ MichaEL S. ENGEL ${ }^{(3,4)}$

(1) Institut de Systématique, Évolution, Biodiversité, ISYEB - UMR 7205 - CNRS, MNHN, UPMC, EPHE, Muséum national d'Histoire naturelle, Sorbonne Universités, 57 rue Cuvier, CP 50, Entomologie, F-75005, Paris, France (anel@mnhn.fr)

(2) Universalmuseum Joanneum, Geology \& Palaeontology, Weinzöttlstrasse 16, A-8045 Graz, Austria (martin.gross@museum-joanneum.at)

${ }^{(3)}$ Division of Entomology, Natural History Museum, and Department of Ecology \& Evolutionary Biology, 1501 Crestline Drive - Suite 140, University of Kansas, Lawrence, Kansas 66045-4415, USA (msengel@ku.edu)

(4) Division of Invertebrate Zoology, American Museum of Natural History, Central Park West at $79^{\text {th }}$ Street, New York, New York 10024-5192, USA 


\begin{abstract}
The first fossil representative of the jewel damselflies (Calopterygoidea: Chlorocyphidae) is described and figured, a family of large, prominent, and often brilliantly colored Old World tropical Zygoptera. Chlorocypha cordasevae n. sp., was recovered from the Late Miocene (Early Pannonian, Serravalian to Tortonian, ca. $11 \mathrm{Ma}$ ) locality of Paldau, in the Styrian Basin, Austria. The fossil seems to be related to the African genus Chlorocypha Fraser, and within a larger group of African genera also including Stenocypha Dijkstra, Africocypha Pinhey, and Platycypha Fraser, and collectively set apart from southern Asiatic genera. The discovery of a central European species of Chlorocypha as recently as the Late Miocene reveals a much wider range to the family than its generally disjunctive modern distribution, demonstrating a Neogene contraction to their range, likely in connection with climatic cooling, drying, and developing seasonality. Modern chlorocyphids live under warm, humid climates, and the presence C. cordasevae in the Pannonian fauna of Paldau further corroborates such a subtropical paleoclimate for the locality at that time.
\end{abstract}

Résumé. Le premier Chlorocyphidae fossile (Calopterygoidea) est décrit et figuré. Ces Zygoptera de la zone intertropicale de l'ancien monde sont souvent brillamment colorés. Chlorocypha cordasevae n. sp. a été découvert dans le Miocène supérieur (Pannonien inférieur, Serravalien à Tortonien, 11Ma.) de Paldau, Bassin de Styrie, Autriche. Ce fossile se rapproche d'un groupe de genres africains modernes qui comprend les genres Chlorocypha Fraser, Stenocypha Dijkstra, Africocypha Pinhey et Platycypha Fraser, distinct de l'ensemble des genres d'Asie du Sud-Est. La découverte en Europe centrale d'une espèce de Chlorocypha dans des niveaux aussi récents que le Miocène supérieur révèle une distribution passée de cette famille beaucoup plus large que celle moderne, disjointe et drastiquement plus réduite. Ce phénomène est probablement en rapport avec avec les changements climatiques mio-pliocènes : refroidissement, assèchement et saisonnalités plus marquées. Les Chlorocyphidae modernes vivent sous des climats chauds et humides. La présence de $C$. cordasevae dans la faune pannonienne de Paldau sont un argument en plus pour l'existence d'un climat subtropical dans cette localité à cette époque.

Keywords: Zygoptera, Calopterygoidea, Neogene, paleogeography, paleoclimate, taxonomy. 
The jewel damselflies (family Chlorocyphidae) comprise approximately 150 species occurring along forest streams in the warm, humid tropics of Africa and Southeast Asia, but are most diverse in the latter. As their common name suggests, many of these damselflies have brightly colored bodies and wings, the latter often with hyaline 'windows' giving characteristic patterns. Alternatively, sometimes only one pair of the wings are colored, giving contrasting appearances between the fore- and hind wings. Species of the family have expanded compound eyes and a comparatively short abdomen, while the naiads are distinctive for their spike-like paraprocts (Bechly 1996). While many zygopteran families are well documented from the fossil record, Chlorocyphidae have hitherto been unknown as fossils (Nel \& Paicheler 1993a). Dumont et al. (2005) in a study of calopterygoid relationships based on ribosomal DNA sequences, estimated the age of crown-group Chlorocyphidae at about $56 \mathrm{Ma}$, right at the Paleocene-Eocene boundary, although their stem extended much deeper, to about $110 \mathrm{Ma}$ (Early Albian), for their purported divergence from Euphaeidae. Given these hypotheses it is perhaps not surprising to have recently discovered a fossil chlorocyphid in Late Miocene deposits, although it is remarkable that the species is from southeastern Central Europe, well north of the present distribution of the family. Here we provide a description and brief discussion of this species, the first fossil jewel damselfly, from the Late Miocene of the Styrian Basin, Austria. The fossil fits well with the general paleoclimate reconstructed for the locality based on its preserved flora, and expands the occurrence of these damselflies into the Neogene of Europe.

\title{
Material and Methods
}

The present specimen was recovered from a gravel pit in the area of Paldau, Austria, one of the three Pannonian-aged deposits known to have produced significant fossil insect material from the Late Miocene of the Styrian Basin (Engel \& Gross 2008a). Engel \& Gross (2008a, 2009) provide geological maps and stratigraphic sections for the locality. The insect remains derive from a plant-rich, pelite layer close to the top of the outcrop, representing a eutrophic floodplain pond bordered by reed and riparian forest, with a warm temperate to nearly subtropical climate as evidenced by the coeval flora (Gross 1998a, 1998b, 2003; Krenn 1998). Several insect groups have been recovered from the Paldau locality (Engel \& Gross 2008a), including beetle elytra, ants, an assassin fly, and most notably a giant archotermopsid termite, Gyatermes styriensis Engel \& Gross (Engel \& Gross 2008b, 2009), as well as a distinctive crane fly, Tipula paleopannonia Engel \& Gross (Engel \& Gross 2012).

In the description, wing venation nomenclature follows that of Riek \& Kukalová-Peck (1984), as amended by Nel et al. (1993) and Bechly (1996). We use the following standard abbreviations: AA anal; AP anal posterior; Ax0, Ax1, Ax2 primary antenodal crossveins; ScP subcostal posterior; $\mathrm{CuA}$ cubitus anterior; IR1, IR2 intercalary radial veins; MAa anterior branch of media anterior; MAb posterior branch of media anterior; MP media posterior; N nodus; ' $\mathrm{O}$ ' oblique vein; RA radius anterior; RP radius posterior. We follow the classification of damselflies proposed by Dijkstra et al. (2014), with some apomorphies as outlined by Bechly (1996).

\section{Systematic Paleontology}

\author{
Suborder Zygoptera Sélys, 1854 \\ Superfamily Calopterygoidea Sélys, 1850
}




\section{Family Chlorocyphidae Cowley, 1937 \\ Genus Chlorocypha Fraser, 1928b, sensu lato}

Chlorocypha cordasevae n. sp.

(Fig. 1)

Holotype. Wing, UMJG\&P 211473, Paldau, Styria; deposited in the Universalmuseum Joanneum, Graz, Austria.

Occurrence. Late Miocene (Early Pannonian, ca. 11.3 Ma), Paldau Formation, Paldau, Styrian Basin, Austria.

Diagnosis. Wing venation characters only: wing hyaline except for a large colored area in distal fifth of wing surrounding and posterior to pterostigma; wing approximately $21 \mathrm{~mm}$ long; pterostigma very broad; no less than 12 longitudinal veins between pterostigma and posterior wing margin; area between C and RP1 distal to pterostigma short; supplementary longitudinal veins between RP1 and IR1 long, beginning proximal to tangent with pterostigmal base; approximately 20 postnodal crossveins and approximately 10 antenodal crossveins.

Description. Forewing, nearly complete, missing only proximal portion of petiolate base (perhaps missing only proximal $\sim 15 \%$ of wing), with part of basal arculus missing, preserved length $18.41 \mathrm{~mm}$ (estimated at total length of $\sim 21 \mathrm{~mm}$ in life), maximum preserved width 4.06 $\mathrm{mm}$; wing hyaline except for darkened wing apex encompassing approximately apical fifth of preserved wing length (darkened area $3.3 \mathrm{~mm}$ long), posterior to pterostigma; distance from arculus to nodus $5.5 \mathrm{~mm}$, from nodus to pterostigma $10.2 \mathrm{~mm}$, from pterostigma to wing apex $1.1 \mathrm{~mm}$; pterostigma large and broad, length $2.1 \mathrm{~mm}$, width $0.5 \mathrm{~mm}$, proximal border of pterostigma strongly oblique, much more so than apical border; pterostigmal brace absent; 19 postnodal crossveins, not aligned with 16 postsubnodal crossveins; ScP strongly oblique, resulting in Z-like form at nodus; nodal crossvein and subnodus aligned and strongly oblique; oblique vein ' $O$ ' absent; nine antenodal crossveins of first row distad Ax2, not aligned with seven antenodals of second row; Ax2 aligned with arculus; RP and MA separated in arculus; basal stem of RP short, only $0.6 \mathrm{~mm}$ long; RP $3 / 4$ aligned with basal stem of RP; RP1/2 forming a strong curve and apparently branching secondarily on RP; base of IR2 $0.6 \mathrm{~mm}$ distad RP3/4; RP3/4 weakly undulate and distally weakly zigzagged; IR2 nearly straight; base of RP2 one cell, $0.6 \mathrm{~mm}$ distad subnodus; base of IR1 three cells, $1.5 \mathrm{~mm}$ distally; RP2 weakly undulate; IR1 basally zigzagged and distally smoothly curved; two relatively long secondary longitudinal veins between RP1 and IR1, beginning just basad pterostigma; two secondary longitudinal veins between IR1 and RP2, RP2 and IR2, one between IR2 and RP3/4, and two between RP3/4 and MAa; discoidal cell long and narrow, length $1.8 \mathrm{~mm}$, width $0.2 \mathrm{~mm}$, with two crossveins; MAa distinctly arched anteriorad at its divergence from MAb; MAa and MP parallel, faintly undulate, with one row of cells between; $\mathrm{CuA}$ strongly zigzagged along most of its apical length, terminating on posterior wing margin $5 \mathrm{~mm}$ distad transverse tangent at nodus; one row of cells between $\mathrm{MP}$ and $\mathrm{CuA}$, and between $\mathrm{CuA}$ and posterior wing margin; base of $\mathrm{AA}$ at least $0.5 \mathrm{~mm}$ basad level of arculus; one row of narrow, elongate cells between AA and posterior wing margin posterior to discoidal cell; subdiscoidal space divided into three cells.

Etymology. The specific epithet honors Danijela Gross (née Čordašev), collector of the holotype and wife to one of us (M.G.).

\section{Discussion}


The present fossil can be attributed to the Calopterygomorpha owing to apomorphic presence of an antenodal area with numerous antenodal crossveins that are placed close together (distance less than $1.0 \mathrm{~mm}$ ), the abrupt kink and Z-like form of ScP at the nodus, the basal curve in RP1/2 which arises from RP with a secondary insertion, and a tendency towards an elongation of the discoidal cell and its subdivision by crossveins. The fossil can be placed within the Chlorocyphidae (sensu Dijkstra et al. 2014), because of the apomorphic presence of an extremely elongate discoidal cell, always traversed by two crossveins; a single row of cells between MP and $\mathrm{CuA}$ (the postsubdiscoidal space not distally widened), and between $\mathrm{CuA}$ and the posterior wing margin; the proximal portion of the antesubnodal space free of crossveins (a.k.a., the 'chlorocyphoid gap'); RP3/4 waving and MA distinctly arched anteriorad immediately distad the discoidal cell; and a zigzagged $\mathrm{CuA}$. The Heliocharitidae (= Dicteriadidae) have similar patterns regarding the discoidal cell, cubito-anal area, and basal curve in RP1/2, but they differ from the Chlorocyphidae (and our fossil) in the presence of crossveins in the basal part of the antesubnodal space. The Devadattidae lack the basal curve in $\mathrm{RP} 1 / 2$ and a broader cubital area with short posterior branches of CuA. The Diphlebiidae and Epallagidae (= Euphaeidae) have no secondary antenodal crossveins between ScP and RA. The other calopterygomorphan families with a similar basal curving of RP1/2 have a broader and different cubito-anal area.

Unfortunately, phylogenetic relationships among the genera of Chlorocyphidae remain 'nebulous'. This reality renders comparison among subgroups within the family challenging and necessitating some comparative comments between the fossil and the entire diversity of Chlorocyphidae as it is presently understood. The fossil from Paldau differs from the genera Libellago Sélys, 1853, Disparocypha Ris, 1916, Watuwila van Tol, 1998 and Sclerocypha Fraser, 1949 by the presence of a strongly curved RP1 at the base of RP3/4, a trait not found among species of any of these extant groups (Ris 1916; Fraser 1949; van Tol 1998). In addition, the species of Disparocypha also have a distinctly shorter $\mathrm{CuA}$ and no AA. Pachycypha Lieftinck, 1950 and Libellago also have only 5-7 antenodal crossveins, unlike the larger number found in the Miocene species. The fossil can similarly be excluded from the genus Melanocypha Fraser, 1949 owing to the presence of only one cell row posterior to $\mathrm{CuA}$ in the former, versus two in the latter (Fraser 1949). Our fossil shares with Rhinocypha Rambur, 1842 the presence of numerous rows of cells between the pterostigma and the posterior wing margin, but species of Rhinocypha have a more elongate pterostigma, bordering more cells, and more antenodal crossveins than the Paldau species (Fraser 1928a; Laidlaw 1936, 1950) [note that Heterocypha Laidlaw, 1950 although listed in the recent catalog of Schorr and Paulson (2016), is a junior synonym of Rhinocypha (Lahiri 1987)]. The fossil differs from Calocypha Fraser, 1928 and Sundacypha Laidlaw, 1950 owing to the origin of AA distal to the level of the arculus (Fraser 1928a; Orr 1999), rather than proximal as is the case in the species from Paldau. The genus Cyrano Needham \& Gyger, 1939 differs from the fossil in the greater number of antenodal crossveins; the space between C and RP1 distal to the pterostigma distinctly longer, as long as the pterostigma itself; and the supplementary longitudinal veins between RP1 and IR1 distinctly shorter, originating distal to the tangent level with the pterostigma (Hämäläinen 1989). The genus Heliocypha Fraser, 1949 differs from the fossil in its greater number of postnodal crossveins and longer pterostigma, bordering many more cells (Hämäläinen 2016), while Paracypha Fraser, 1949 differ in the larger number of antenodal crossveins and presence of two rows of cells between $\mathrm{CuA}$ and the posterior wing margin (Fraser 1949). The Paldau fossil 
differs from Indocypha Fraser, 1949 by the greater number of antenodal crossveins and the distinctly shorter supplementary longitudinal veins between RP1 and IR1 in the latter (Fraser 1949; Zhang et al. 2010; Hämäläinen 2014), while, Rhinoneura Laidlaw, 1915 have much more narrow wings and a far greater number of postnodal crossveins (Laidlaw 1915) than does the Miocene species. Lastly, in Aristocypha Laidlaw the 'chlorocyphoid gap' is less pronounced and $\mathrm{CuA}$ is distinctly shorter than is the case in the species from Paldau (Wilson 2004; Hämäläinen et al. 2009).

The African group of genera - Chlorocypha Fraser, 1928, Stenocypha Dijkstra, 2013, Africocypha Pinhey, 1961, and Platycypha Fraser, 1949 - form one of the few, clearly monophyletic groups among the family and are considered as the 'clear-winged Chlorocyphinae' (Dijkstra et al. 2014; Bechly 1996). Among all chlorocyphids, this clade is more closely aligned to the Paldau fossil than any of the aforementioned groups. These African genera and the fossil share similar forms to the main veins and widened pterostigma, relatively reduced numbers of antenodal (around 12) and postnodal (between 15 and 20) crossveins, and the form of RP1/2, and comparatively largely hyaline wings among most species. The fossil differs from them in the relatively reduced number of secondary veins between the pterostigma and the posterior wing margin. The distinctions between the extant African genera are based on characters of the body, legs, and genitalia (Munz 1919; Fraser 1949; Pinhey 1967; Dijkstra 2013), obviously none of which are preserved in the fossil from Paldau. Accordingly, a precise and confident generic placement for the fossil is not possible, and we provisionally attribute the species to Chlorocypha s.1. (Fraser 1928b; Dijkstra 2003; Kipping et al. 2017). Hopefully, more complete material will become available and permit refinement of this assignment.

Although Dumont et al. (2005) recovered a euphaeid-chlorocyphid clade, there remains some uncertainty regarding the sister group to Chlorocyphidae (Dijkstra et al. 2014). Given the lack of definitive resolution among calopterygoid families, it is difficult to distinguish between hypotheses regarding the patterns of diversification across the clade. In one of their analyses, Dijkstra et al. (2014) considered the Asiatic Devadattidae as the most probable sister group to Chlorocyphidae, which might suggest that the clade diversified in Asia, with subsequent dispersion into Africa among the chlorocyphids. The presence of Miocene terrestrial connections between Africa and Europe (Rögl 1998) would therefore be consistent with a species of the African clade extending northward into suitable habitats present in Europe at the time. However, Garrouste et al. (in press) have recently described a devadattid-like damselfly from the Paleocene of France, suggesting that devadattids were possibly also present in the Paleogene of Europe. Thus, if devadattids are truly sister to chlorocyphids, then it is possible that the pattern may be reversed, with initial diversification of the crown-group Chlorocyphidae in the Paleogene of Europe, with subsequent expansion into Africa and Asia, and then later extinction across the north as more temperate climates became established in the latter Neogene. In another analysis, Dijkstra et al. (2014) recovered the Madagascan genus Protolestes Förster, 1899 as a possible sister group to Chlorocyphidae (but with rather low support), which could support a Gondwanan origin for the two clades.

Alternatively, the Chlorocyphidae, or perhaps even stem-groups to Devadattidae and Chlorocyphidae, were widespread across Eurasia and possibly Africa during the PaleoceneEocene, with considerable extinction during the Neogene giving the restricted patterns of distribution we observe among the modern diversity. This last scenario would be analogous to other major contractions observed among insect groups subsequent to the Eocene-Oligocene transition, such as Rhachiberothidae, Mastotermitidae, and Archotermopsidae (Engel 2004; 
Wappler \& Engel 2006; Engel et al. 2007; Engel \& Grimaldi 2008; Engel \& Gross 2009; McKellar \& Engel 2009; Krishna et al. 2013). The pattern of occurrence observed for Chlorocyphidae is also mirrored among the termitid subfamily Macrotermitinae; present today in Africa and Asia, and in the Late Miocene of France and Germany (Nel \& Paicheler 1993b; Krishna et al. 2013); and the gomphid subfamily Lindeniinae, today in Africa, Asia, and Australia, but also in the mid-Miocene of Austria (Schädel \& Lechner 2017). The presence of the modern African damselfly genus Sapho Selys, 1853 in the latest Oligocene of France also supports the hypothesis of significant contact between these areas during the late Paleogene and early Neogene (Nel \& Petrulevičius 2010). At present all of the aforementioned scenarios are consistent with the relationships and occurrence of taxa as currently understood.

\section{Conclusion}

Regardless of the historical biogeography at play, the discovery of a chlorocyphid in the deposits of Paldau is consistent with the general paleoclimate as it has been reconstructed on the basis of the preserved flora, which indicates a warm and humid climate (Krenn 1998). The deposit was formed in lake or pond situation bordered by forest, which is further consistent with the habitat preferences of modern Chlorocyphidae. The fossil chlorocyphid, along with the presence of Gyatermes styriensis (Engel \& Gross 2009), serve to corroborate the current model of Paldau's paleoenvironment.

Acknowledgements. We are thankful to two anonymous reviewers for their comments on an earlier draft of the manuscript, and particularly K.-D. Dijkstra for his many critical insights regarding the present fossil. This is a contribution of the Division of Entomology, University of Kansas Natural History Museum.

\section{References}

Bechly G. 1996. Morphologische Untersuchungen am Flügelgeäder der rezenten Libellen und deren Stammgruppenvertreter (Insecta: Pterygota: Odonata), unter besonderer Berücksichtigung der Phylogenetischen Systematik und des Grundplanes der Odonata. Petalura, Special Volume 2: 1-402.

Cowley J. 1937. The penis of the Chlorocyphidae (Odonata) as a group-character. Transactions of the Royal Entomological Society of London 86(1): 1-18.

Dijkstra K.-D.B. 2003. Problems in Chlorocypha classification: four cases from West Africa and a discussion of the taxonomic pitfalls (Odonata: Chlorocyphidae). International Journal of Odonatology 6(2): 109-126.

Dijkstra K.-D.B. 2013. Three new genera of damselflies (Odonata: Chlorocyphidae, Platycnemididae). International Journal of Odonatology 16(3): 269-274.

Dijkstra K.-D.B., Kalkman V.J., Dow R.A., Stokvis F.R., van Tol J. 2014. Redefining the damselfly families: a comprehensive molecular phylogeny of Zygoptera (Odonata). Systematic Entomology 39(1): 68-96.

Dumont H.J., Vanfleteren J.R., De Jonckheere J.F., Weekers P.H.H. 2005. Phylogenetic relationships, divergence time estimation, and global biogeographic patterns of calopterygoid damselflies (Odonata, Zygoptera) inferred from ribosomal DNA sequences. Systematic Biology 54(3): 347-362. 
Engel M.S. 2004. Thorny lacewings (Neuroptera: Rhachiberothidae) in Cretaceous amber from Myanmar. Journal of Systematic Palaeontology 2(2): 137-140.

Engel M.S., Grimaldi D.A. 2008. Diverse Neuropterida in Cretaceous amber, with particular reference to the paleofauna of Myanmar (Insecta). Nova Supplementa Entomologica 20: $1-86$.

Engel M.S., Gross M. 2008a. The Pannonian insect fauna of Styria: a preliminary overview. Austrian Journal of Earth Sciences 101: 52-59.

Engel M.S., Gross M. 2008b. A giant fossil termite from the Late Miocene of Austria. Journal of Alpine Geology 49: 21.

Engel M.S., Gross M. 2009. A giant termite from the Late Miocene of Styria, Austria (Isoptera). Naturwissenschaften 96(2): 289-295.

Engel M.S., Gross M. 2012. A new fossil crane fly from the Early Pannonian of the Styrian Basin (Diptera: Tipulidae). Journal of the Kansas Entomological Society 85(2): 160-163.

Engel M.S., Grimaldi D.A., Krishna K. 2007. A synopsis of Baltic amber termites (Isoptera). Stuttgarter Beiträge zur Naturkunde, Serie B, Geologie und Paläontologie 372: 1-20.

Fraser F.C. 1928a. Indian dragonflies. Part xxix. Journal of the Bombay Natural History Society 32(4): $450-459,+3$ pls.

Fraser F.C. 1928b. Indian dragonflies. Part xxx. Journal of the Bombay Natural History Society 32(4): 683-691, +3 pls.

Fraser F.C. 1949. A revision of the Chlorocyphidae with notes on the classification of the Selysian species rubida, glauca, cyanifrons and curta. Bulletin de l'Institut Royal des Sciences Naturelles de Belgique 25(6): 1-50.

Garrouste R., Wedmann S., Pouillon J.-M., Nel A. In press. The oldest 'amphipterygid' damselfly of tropical affinities in the Paleocene of Menat (Zygoptera: Eucaloptera). Historical Biology

Gross M. 1998a. Floren- und Faziesentwicklung im Unterpannonium (Obermiozän) des Oststeirischen Neogenbeckens (Österreich). Geologisch-Paläontologische Mitteilungen Innsbruck 23: 1-35.

Gross M. 1998b. Faziesanalyse fluviatiler Sedimente (Obermiozän, Südoststeiermark, Österreich). Mitteilungen Geologie und Paläontologie am Landesmuseum Joanneum 56: 131-164.

Gross M. 2003. Beitrag zur Lithostratigraphie des Oststeirischen Beckens (Neogen/Pannonium; Österreich). Österreichische Akademie der Wissenschaften, Schriftenreihe der Erdwissenschaftlichen Kommissionen 16: 11-62.

Hämäläinen M. 1989. Revision of the Philippine genus Cyrano Needham \& Gyger (Odonata, Chlorocyphidae). Annales Entomologici Fennici 55(3): 121-127.

Hämäläinen M. 2014. Indocypha neglecta sp. nov. from northern Vietnam (Odonata: Chlorocyphidae). Odonatologica 43(1-2): 79-90.

Hämäläinen M., Reels G.T., Zhang H.-M. 2009. Description of Aristocypha aino sp. nov. from Hainan, with notes on the related species (Zygoptera: Chlorocyphidae). Tombo, Acta Odonatologica Japonica 51: 16-22.

Hämäläinen M. 2016. Description of Heliocypha vantoli spec. nov. from Siberut in the Mentawai Islands (Odonata: Chlorocyphidae). Zootaxa 4079(4): 495-500.

Kipping, J., Clausnitzer, V., Elizalde, S.R.F., Dijkstra, K.-D.B. 2017. The dragonflies and damselflies (Odonata) of Angola. African Invertebrates 58(1): 65-91. 
Krenn H. 1998. Die obermiozäne (pannone) Flora von Paldau, Steiermark, Österreich. Mitteilungen Geologie und Paläontologie am Landesmuseum Joanneum 56: 165-271.

Krishna K., Grimaldi D.A., Krishna V., Engel M.S. 2013. Treatise on the Isoptera of the world. Bulletin of the American Museum of Natural History 377: 1-2704.

Lahiri A.R. 1987. Studies on the odonate fauna of Meghalaya. Records of the Zoological Survey of India, Occasional Paper 99: 1-402.

Laidlaw F.F. 1915. Contributions to a study of the dragonfly fauna of Borneo.-Part III. A collection made on Mount Kina Balu by Mr. J.C. Moulton in September and October 1913. Proceedings of the Zoological Society of London 1915: 25-39.

Laidlaw F.F. 1936. Note on some species of Rhinocypha with description of a new species. Journal of the Federated Malay States Museums 18(1): 60-64, +1 pl.

Laidlaw F.F. 1950. A survey of the Chlorocyphidae (Odonata: Zygoptera), with diagnoses of proposed new genera, and description of a new geographical subspecies. Transactions of the Royal Entomological Society of London 101(8): 257-280.

McKellar R.C., Engel M.S. 2009. A new thorny lacewing (Neuroptera: Rhachiberothidae) from Canadian Cretaceous amber. Journal of the Kansas Entomological Society 82(2): 114 121.

Munz P.A. 1919. A venational study of the suborder Zygoptera (Odonata) with keys for the identification of genera. Memoirs of the American Entomological Society 3: 1-78.

Nel A., Paicheler J.-C. 1993a. Les Odonata fossiles: état actuel des connaissances. Huitième partie: les Calopterygoidea fossiles (Odonata, Zygoptera). Bulletin de la Société Entomologique de France 97(4): 381-396.

Nel A., Paicheler J.-C. 1993b. Les Isoptera fossiles. État actuel des connaissances, implications paléoécologiques et paléoclimatologiques [Insecta, Dictyoptera]. Cahiers de Paléontologie 1993: 103-179.

Nel, A., Petrulevičius J.F. 2010. Afrotropical and Nearctic genera of Odonata in the French Oligocene: biogeographic and paleoclimatic implications (Insecta: Calopterygidae and Aeshnidae). Annales de la Société Entomologique de France (N.S.) 46(1-2): 228-236.

Nel A., Martínez-Delclòs X., Paicheler J.-C., Henrotay M. 1993. Les 'Anisozygoptera' fossiles. Phylogénie et classification (Odonata). Martinia, Numéro Hors Série 3: 1-311.

Orr A.G. 1999. Sundacypha striata spec. nov., a new damselfly from Borneo (Zygoptera: Chlorocyphidae). Odonatologica 28(2): 181-185.

Pinhey E. 1967. African Chlorocyphidae (Odonata). Journal of the Entomological Society of Southern Africa 29(1): 161-197.

Riek E.F., Kukalová-Peck J. 1984. A new interpretation of dragonfly wing venation based upon Early Carboniferous fossils from Argentina (Insecta: Odonatoidea) and basic characters states in pterygote wings. Canadian Journal of Zoology 62(6): 1150-1166.

Ris F. 1916. Zwei Notizen über Calopterygiden (Odonata) vom Malaiischen Archipel. Entomologische Mitteilungen 5(9-12): 303-318.

Rögl F. 1998. Palaeogeographic considerations for Mediterranean and Paratethys seaways (Oligocene to Miocene). Annalen des Naturhistorischen Museums in Wien, Serie A 99: 279-310, +10 pls.

Schädel M., Lechner T.S. 2017. Two new dragonflies (Odonata: Anisoptera) from the Miocene of Carinthia (Austria). Zootaxa 4243(1): 153-164. 
Schorr M., Paulson D. 2016. World Odonata List.

[https://www.pugetsound.edu/academics/academic-resources/slater-museum/biodiversityresources/dragonflies/world-odonata-list2/; last accessed 17 March 2017]

Sélys Longchamps E. de 1850. Revue des odonates ou libellules d'Europe. C. Muquardt, Bruxelles, xxii +408 pp., +11 pls.

Sélys Longchamps E. de 1854. Monographie des Caloptérygines. C. Muquardt, Bruxelles, $\mathrm{xi}+291$ pp., $+14 \mathrm{pls}$.

van Tol J. 1998. The Odonata of Sulawesi and adjacent islands. Part 4. A new genus and species of Chlorocyphidae from South-East Sulawesi. Zoologische Verhandelingen 323: 441448.

Wappler T., Engel M.S. 2006. A new record of Mastotermes from the Eocene of Germany (Isoptera: Mastotermitidae). Journal of Paleontology 80(2): 380-385.

Wilson K.D.P. 2004. New Odonata from South China. Odonatologica 33(4): 423-432.

Zhang H.-M., Hämäläinen M., Tong X. 2010. Indocypha catopta sp. nov. from Guizhou, China (Odonata: Chlorocyphidae). International Journal of Odonatology 13(2): 231-240. 


\section{FIGURE CAPTIONS}

\section{Figure 1}

Holotype of Chlorocypha cordasevae n. sp. (UMJG\&P 211473), from the Late Miocene (Pannonian) of the Styrian Basin, Austria. A, photograph of holotype as preserved; B, Line drawing of preserved venational details, with major landmarks and veins noted.
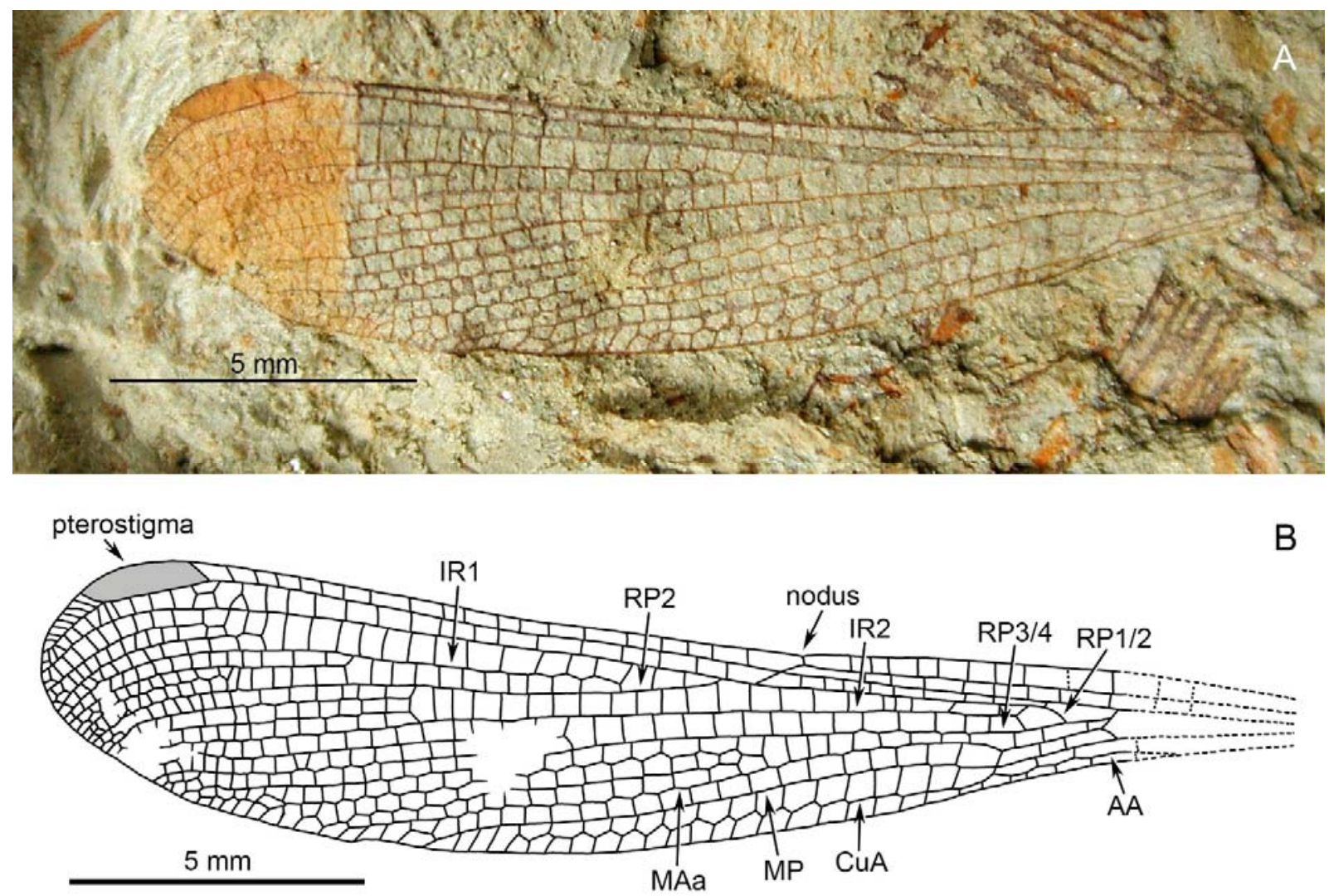
premaser.

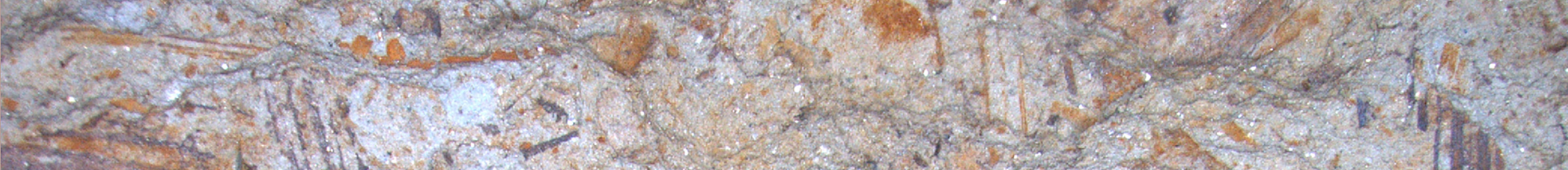

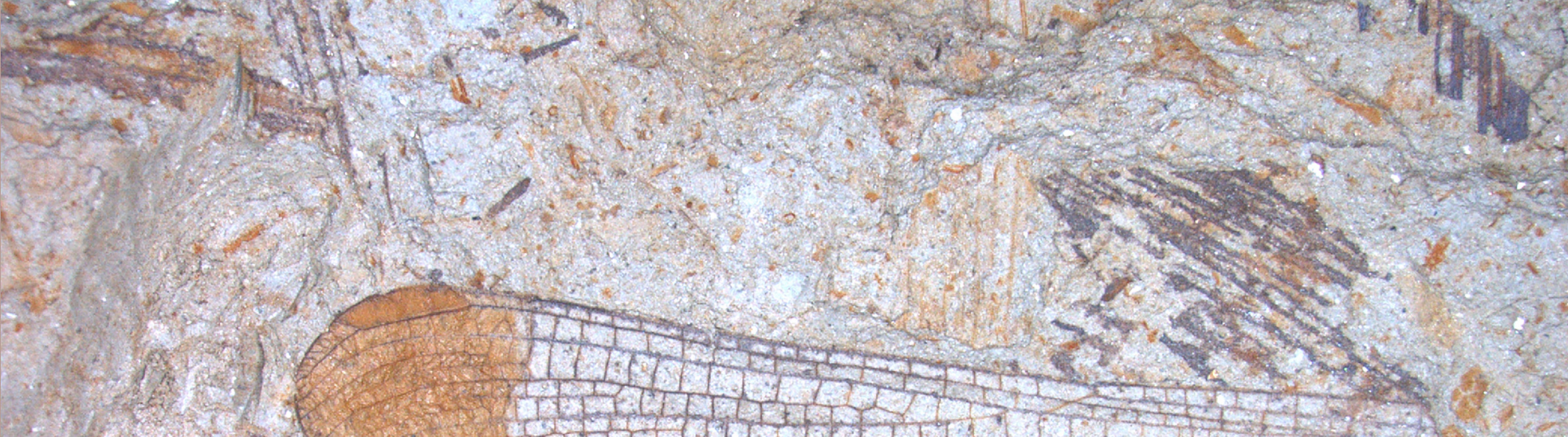

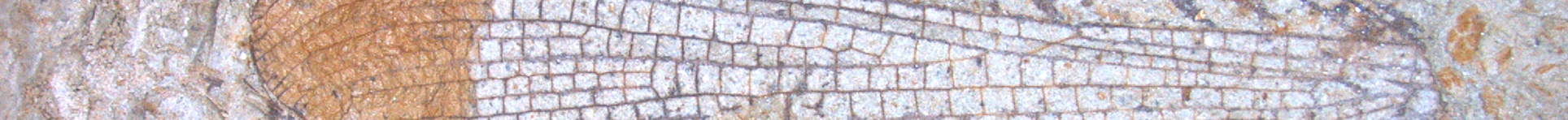

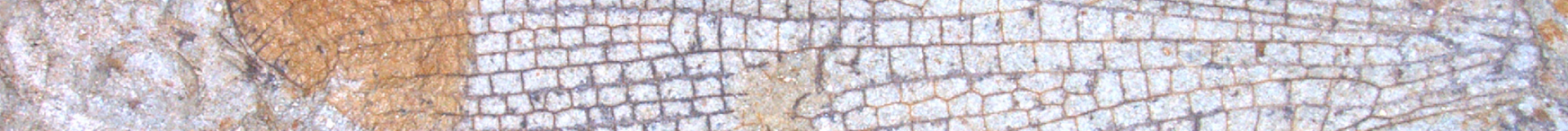

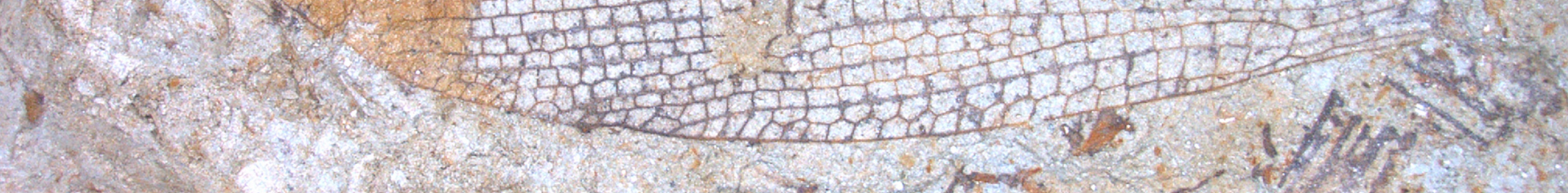

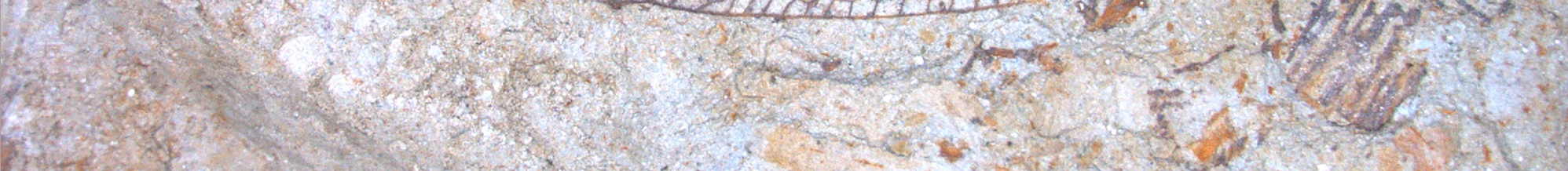

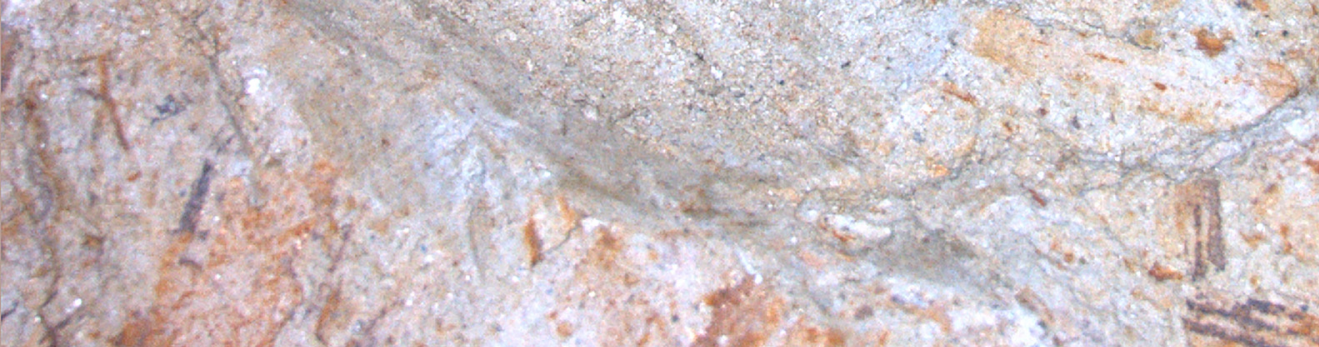




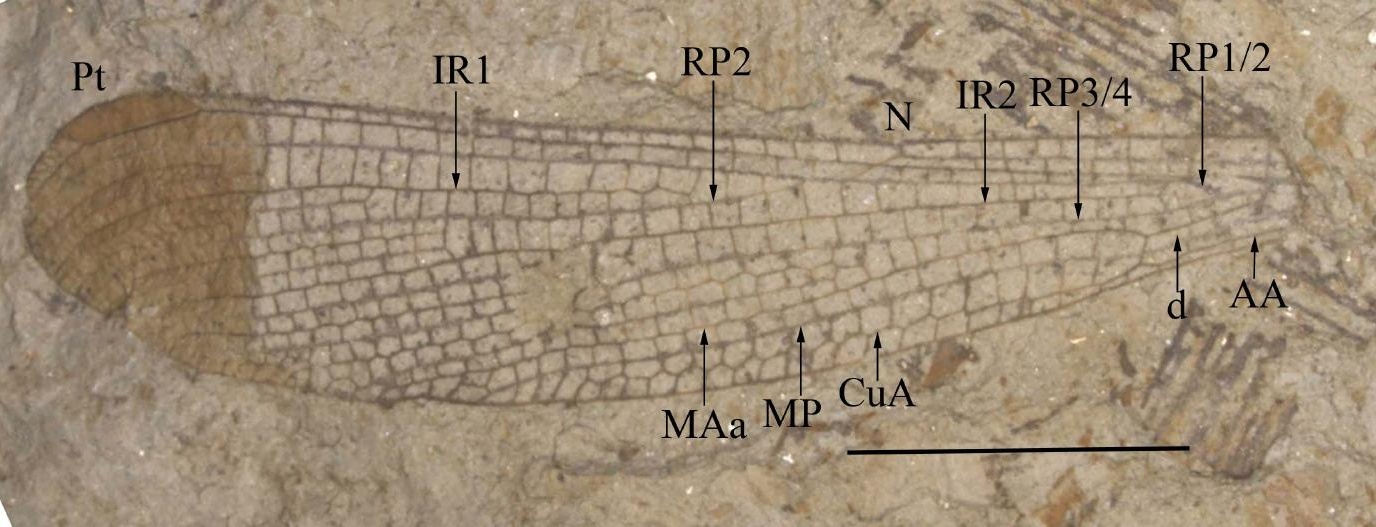




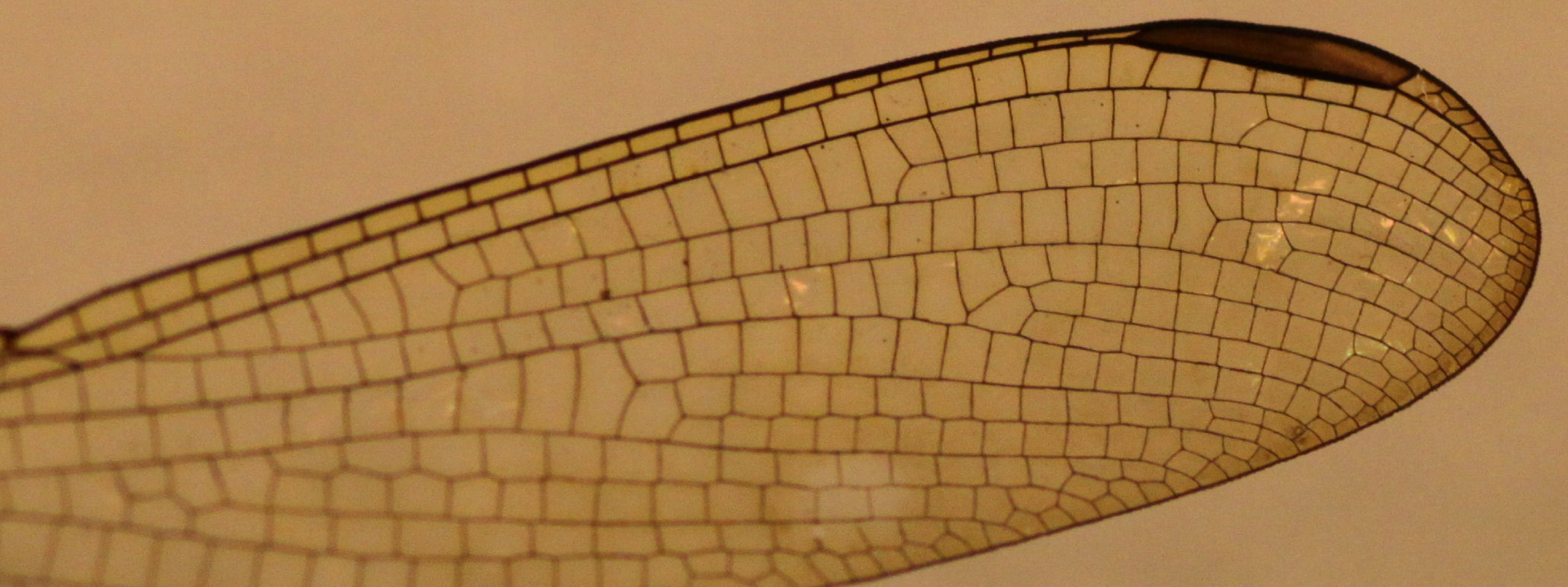



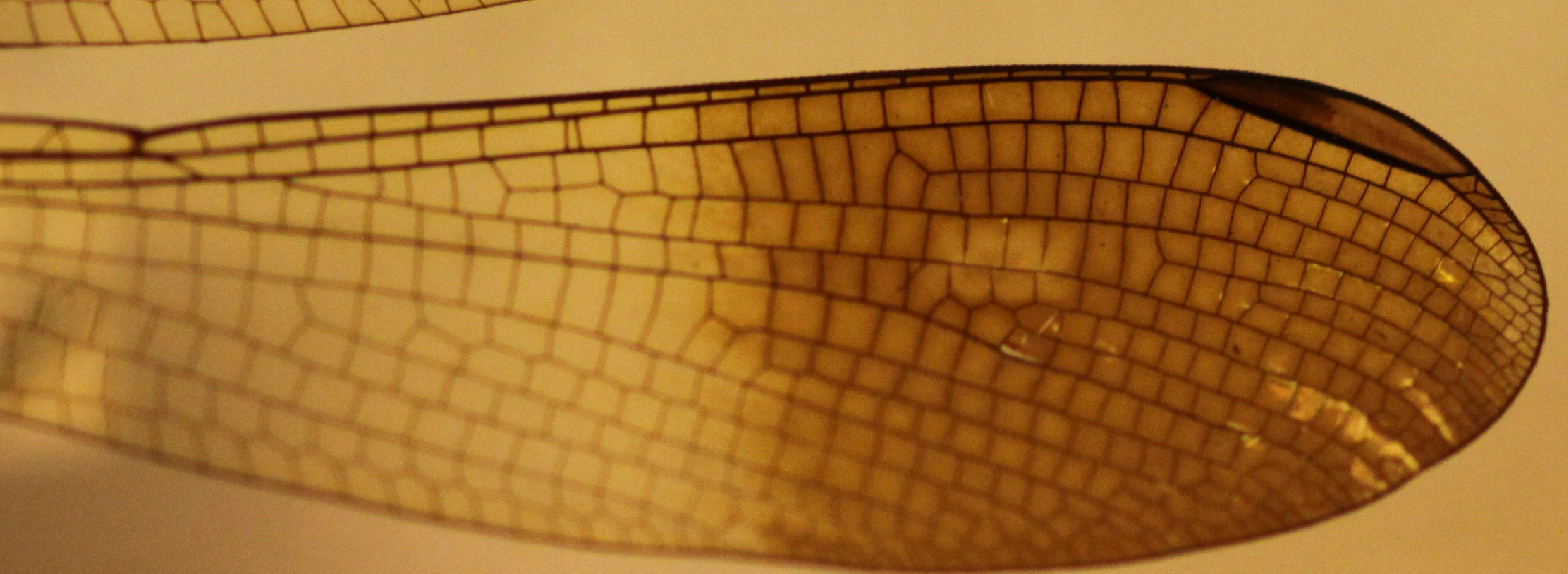